\title{
Analysis on the Synergistic Effect of M\&A from the Perspective of Finance-A Case Study of China Zhonghua Geotechnical Engineering Co.,Ltd
}

\author{
Mengya Wang \\ International Business School \\ Shaanxi Normal University, SNNU \\ Xi'an, China
}

\begin{abstract}
As one of the motivation of merger and acquisition, an effective means to enlarge the capital operation scale of enterprises, synergistic effect is key to the future development of enterprises after M\&A. Therefore, it is of great practical significance to study the synergy effect of M\&A, which can help to effectively implement the integration after $M \& A$, to give full play to the financial synergy effect, to promote the M\&A to achieve the desired effect, and to enhance the comprehensive strength of the enterprises. This paper studies the synergistic effect of M\&A from the perspective of financial synergy, operating synergy and management synergy by analyzing financial indexes of China Zhonghua Geotechnical Engineering Co.,Ltd from 2013 to 2017, and then tries to provide some references for enterprise planning to accomplish $M \& A$.
\end{abstract}

Keywords-Synergistic effect; Financial synergy; Operating synergy; Management synergy; Financial indexes

\section{INTRODUCTION}

Mergers and acquisitions is an important approach for enterprises to develop and expand rapidly in the market economy system and obtain efficient capital operation and improve overall efficiency [1]. Compared with enterprises who realize development on its own accumulation, mergers and acquisitions is significantly more efficient way of developing, as it can rapidly expand scale, increase market share, improve the industry chain to enhance the competitiveness of enterprises. It is realization of synergistic effect that determines whether enterprises could develop in an expected approach to the desirable direction. The realization of synergy is the key factor to evaluate the success of mergers and acquisitions [2]. Therefore, we hopes to make some suggestions for future M \& A by studying the realization of synergy effect. In this paper, we will study the case of China Zhonghua Geotechnical Engineering Co.,Ltd and put forward several suggestions.

\section{THEORY REVIEW}

Financial analysis is a method to evaluate the condition of economic organization from perspective of profitability, debt paying ability, growing ability etc.. Based on data from financial statements, it can provide accurate information or basis for stakeholders including investor, creditor, operator and other subjects concerned with enterprise to get information of the past, evaluate the present situation of the enterprise, and predict the correct decision of the enterprise in the future. In consideration of the reliability and validity of financial analysis, we decide to analysis synergistic effect from perspective of finance [3]. According to the previous research, synergistic effect can be divided into the following categories: financial synergy, operating synergy and management synergy. Operating synergy can be evaluated from profitability and growth ability, management synergy is generally appraised from perspectives of asset management capability and expense control ability while financial synergy is normally estimated from aspects of debt paying ability and tax saving. The specific evaluation indicators are shown in the following three tables.

TABLE I. OPERATING SYNERGIES FINANCIAL ANALYSIS INDICATORS

\begin{tabular}{|c|c|c|}
\hline \multirow{4}{*}{$\begin{array}{c}\text { Key } \\
\text { Points }\end{array}$} & Core Indicators & Acronym \\
\hline \multirow{4}{*}{$\begin{array}{l}\text { Growth } \\
\text { Ability }\end{array}$} & Net Cash Flow Per Share from Operating & NCFPS \\
\cline { 2 - 3 } & Activities (\%) & RGR \\
\cline { 2 - 3 } & Revenue Growth Rate (\%) & CPMR \\
\hline \multirow{4}{*}{$\begin{array}{l}\text { Profitab } \\
\text { ility }\end{array}$} & Rate of Return on Common Stockholders' Equity & ROE \\
\cline { 2 - 3 } & Return on Total Assets Ratio & ROA \\
\cline { 2 - 3 } & Net profit margin & NPM \\
\cline { 2 - 3 } & Gross profit margin & GPM \\
\cline { 2 - 3 } & Operating Profit Ratio & OPR \\
\hline
\end{tabular}


TABLE II. MANAGEMENT SYNERGIES FINANCIAL ANALYSIS INDICATORS

\begin{tabular}{|c|c|c|}
\hline Key Points & Core Indicators & Acronym \\
\hline \multirow{6}{*}{$\begin{array}{l}\text { Asset } \\
\text { management Cap } \\
\text { ability }\end{array}$} & Inventory Turnover & IT \\
\hline & Accounts Receivables Turnover & ART \\
\hline & Current Assets Turnover & CAT \\
\hline & Fixed Assets Turnover & FAT \\
\hline & Total Assets Turnover & TAT \\
\hline & Working Capital Turnover & WCT \\
\hline \multirow{3}{*}{$\begin{array}{l}\text { Cost } \\
\text { Ability }\end{array}$} & Selling Expenses/Operating Revenue & SE/OR \\
\hline & Management Fees/ & $\mathrm{MF} / \mathrm{OR}$ \\
\hline & Financial Expenses/Operating Revenue & FE/OR \\
\hline
\end{tabular}

TABLE III. FINANCIAL SYNERGIES FINANCIAL ANALYSIS INDICATORS

\begin{tabular}{|c|c|c|}
\hline Key Points & Core Indicators & Acronym \\
\hline \multirow{10}{*}{$\begin{array}{l}\text { Debt-paying } \\
\text { Ability }\end{array}$} & Current Ratio & $\mathrm{CR}$ \\
\hline & Current Ratio of GEC/that of Industry Average & GEC/IA \\
\hline & Quick Ratio & QR \\
\hline & Quick Ratio of GEC/that of Industry Average & GEC/IA \\
\hline & Equity Multiplier & EM \\
\hline & Equity Multiplier of GEC/that of Industry Average & GEC/IA \\
\hline & Equity Ratio & ER \\
\hline & Equity Ratio of GEC/that of Industry Average & GEC/IA \\
\hline & Assets-liabilities Ratio & ALR \\
\hline & Assets-liabilities Ratio of GEC/that of Industry Average & GEC/IA \\
\hline \multirow[b]{2}{*}{$\begin{array}{l}\text { Tax-saving } \\
\text { Ability }\end{array}$} & Total Income Tax & TIT \\
\hline & Total Income Tax/Average Assets & TIT/AA \\
\hline
\end{tabular}

III. CASE OF SYNERGY

China Zhonghua Geotechnical Engineering Co., Ltd ("GEC" or "company") was founded in December 2001 and listed on the Shenzhen Stock Exchange in January 2011. According to information revealed openly by company, there are $\mathrm{M} \& \mathrm{~A}$ in 2014 and 2016. As a result, we analysis the financial factors from 2013 to 2017 to evaluate the achievement of mergers from perspective of finance.

\section{A. Operating Synergy}

Growth capacity. Under the competition of market economy, the growth ability of enterprises determines the trend and speed of future development of enterprises, which can be used to predict the sustainability of enterprises' future profitability [4].

TABLE IV. GROWTH CAPACITY INDEX

\begin{tabular}{|l|c|c|c|c|c|}
\hline \multirow{2}{*}{$\begin{array}{c}\text { Index } \\
(\boldsymbol{\%})\end{array}$} & \multicolumn{5}{|c|}{ Year } \\
\cline { 2 - 6 } & $\mathbf{2 0 1 3}$ & $\mathbf{2 0 1 4} *$ & $\mathbf{2 0 1 5}$ & $\mathbf{2 0 1 6}$ & $\mathbf{2 0 1 7}$ \\
\hline NCFPS & 210.20 & -272.69 & 79.54 & 4.88 & 192.42 \\
\hline RGR & 11.91 & 138.53 & 60.38 & 19.48 & 21.05 \\
\hline CPMR & 121.35 & 786.79 & 91.53 & 261.67 & 180.68 \\
\hline
\end{tabular}

As tabke4 shows, NCFPS decreased largely when mergers taken which indicate that company's ability to pay dividends was improved after M\&A. The revenue growth rate varies greatly, but it was generally higher than before the mergers and acquisitions. The capital project maintenance rate increased significantly in the year of mergers and acquisitions. Compared with the period before mergers and acquisitions, this figure increased by $49 \%$ in 2007 and was greater than 1, indicating that the scale of the company is expanding.

Profitability. The indicators in Table 5 did not change much before and after the merger but the overall trend was reduced [5]. Although the decline in ROE was affected by the increase in asset impairment losses after the acquisition (WIND), the underlying reason was the increase in cost of sales. That is, the profitability of enterprises after mergers and acquisitions has not improved, indicating that cost management and expense management should be intensified. In general, the synergy effect of mergers and acquisitions has a significant effect on the growth capability of enterprises after M\&A, which was reflected in the capital project maintenance rate. The trend of development of GEC is good, but the profitability is not optimistic and needs to be improved. 
TABLE V. PROFITABILITY

\begin{tabular}{|l|c|c|c|c|c|}
\hline \multirow{2}{*}{ Index (\%) } & \multicolumn{5}{|c|}{ Year } \\
\cline { 2 - 6 } & $\mathbf{2 0 1 3}$ & $\mathbf{2 0 1 4}$ & $\mathbf{2 0 1 5}$ & $\mathbf{2 0 1 \boldsymbol { F } ^ { * }}$ & $\mathbf{2 0 1 7}$ \\
\hline ROE & 8.62 & 10.34 & 10.62 & 8.48 & 7.04 \\
\hline ROA & 7.67 & 8.15 & 8.24 & 10.57 & 5.23 \\
\hline NPM & 14.01 & 10.81 & 11.67 & 25.80 & 8.55 \\
\hline GPM & 26.10 & 27.38 & 29.17 & 12.61 & 23.53 \\
\hline OPR & 16.31 & 12.25 & 13.59 & 10.23 \\
\hline
\end{tabular}

\section{B. Management Synergy}

Asset management capability, also called operational capability, is the ability of an enterprise to use assets to realize revenue [6]. As it can be seen from Table 6, the working capital turnover rate has increased significantly, which shows that the utilization efficiency of working capital after M\&A has been greatly improved. The inventory turnover rate fell from 3.64 to 1.30 , a decrease of $64.17 \%$, indicating that the company's inventory has been overstocked in recent years. According to the JRJ. COM, the number of GEC's total asset turnover rate divided by the industry average is $0.56,0.62,0.54$ 0.54 , and 0.76 . Overall, the company's operating capability is slightly improved. The turnover rate of accounts receivable decreased slightly in 2017. The rage and trend of change in Fixed Assets Turnover, Current Assets Turnover, and Total Assets Turnover were similar to that of Receivables Turnover, and all of them fluctuated in a small range which indicates that the main reason for the apparent improvement in the asset operating capacity may be due to the slow turnover of the inventory, and the decrease in the flow of the company from input to output.

TABLE VI. ASSET MANAGEMENT CAPABILITY

\begin{tabular}{|c|c|c|c|c|c|}
\hline \multirow{2}{*}{ Index(times/year) } & \multicolumn{5}{|c|}{ Year } \\
\cline { 2 - 6 } & $\mathbf{2 0 1 3}$ & $\mathbf{2 0 1 4 ^ { * }}$ & $\mathbf{2 0 1 5}$ & $\mathbf{2 0 1 6 ^ { * }}$ & $\mathbf{2 0 1 7}$ \\
\hline IT & 3.64 & 1.74 & 1.30 & 1.25 & 1.30 \\
\hline ART & 1.99 & 1.99 & 2.03 & 2.06 & 1.80 \\
\hline CAT & 0.72 & 0.89 & 0.74 & 0.68 & 0.70 \\
\hline FAT & 2.96 & 2.84 & 2.96 & 2.88 & 2.54 \\
\hline TAT & 0.52 & 0.60 & 0.50 & 0.44 & 0.45 \\
\hline WCT & 0.93 & 2.00 & 2.08 & 1.91 & 2.26 \\
\hline
\end{tabular}

Cost control capability refers to the ability of an enterprise to control the occurrence of expenses in its daily operations. It can be seen from Table 7 that the proportion of Selling Expenses, Management Fees and Financial Expenses both increased after GEC's merger and acquisition. According to the financial statements, the increase in the proportion of administrative expenses was mainly due to the increase in Research and Development expenses, salary and salaries of managers, and increase in intermediary agency fees. The change in the proportion of Financial Expenses was mainly due to changes in interest of Bank Loan. The increase in Sales Expenses was mainly due to the increase in salaries and wages cost in the sales department and the increase in Travel Expenses and Business Entertainment Expenses. This situation shows that company needs strengthened the cost control ability, especially in terms of Business Entertainment Expenses and Bank Loan Interest. In general, although the efficiency of the use of total assets and working capital has been improved slightly, the ability to operate after mergers and acquisitions did not be improved and the cost control ability needs to be improved.
TABLE VII. COST CONTROL CAPABILITY

\begin{tabular}{|l|c|c|c|c|c|}
\hline \multirow{2}{*}{$\begin{array}{c}\text { Index } \\
(\boldsymbol{\%})\end{array}$} & \multicolumn{5}{|c|}{ Year } \\
\cline { 2 - 6 } & $\mathbf{2 0 1 3}$ & $\mathbf{2 0 1 4 ^ { * }}$ & $\mathbf{2 0 1 5}$ & $\mathbf{2 0 1 6}^{*}$ & $\mathbf{2 0 1 7}$ \\
\hline SE/OR & 0.41 & 0.59 & 0.70 & 0.67 & 0.81 \\
\hline MF/OR & 6.91 & 7.36 & 8.03 & 9.29 & 8.71 \\
\hline FE/OR & -1.47 & 1.23 & 2.87 & 2.11 & 1.65 \\
\hline
\end{tabular}

\section{Financial Synergy}

Debt Paying Ability. From Table 8, we can see that the Quick Ratio and Current Ratio reduced, and the ratios between these two indicators and the industry average also decreased, indicating that the Short-term Debt-paying Ability of the company was declining. This may be affected by the fact that GEC paid cash as consideration of mergers and acquisitions. 
TABLE VIII. DEBT-PAYING ABILITY

\begin{tabular}{|l|c|c|c|c|c|}
\hline \multirow{2}{*}{ Index (\%) } & \multicolumn{5}{|c|}{ Year } \\
\cline { 2 - 6 } & $\mathbf{2 0 1 3}$ & $\mathbf{2 0 1 4}$ & $\mathbf{2 0 1 5}$ & $\mathbf{2 0 1 6}$ & $\mathbf{2 0 1 7}$ \\
\hline CR & 4.16 & 1.51 & 1.58 & 1.53 & 1.39 \\
\hline GEC/IA ${ }^{2}$ & $148.57 \%$ & $81.18 \%$ & $69.00 \%$ & $68.92 \%$ & $73.94 \%$ \\
\hline QR & 3.30 & 0.86 & 0.97 & 0.88 & 0.83 \\
\hline GEC/IA & $138.66 \%$ & $60.99 \%$ & $56.73 \%$ & $52.69 \%$ & $56.46 \%$ \\
\hline EM & 1.20 & 1.80 & 1.76 & 1.73 & 1.97 \\
\hline GEC/IA & $43.48 \%$ & $57.32 \%$ & $67.69 \%$ & $60.49 \%$ & $70.86 \%$ \\
\hline ER & 0.20 & 0.80 & 0.76 & 0.73 & 0.97 \\
\hline GEC/IA & $11.36 \%$ & $37.38 \%$ & $47.50 \%$ & $39.25 \%$ & $54.49 \%$ \\
\hline ALR & 0.17 & 0.44 & 0.43 & 0.42 & 0.49 \\
\hline GEC/IA & $26.14 \%$ & $65.21 \%$ & $70.17 \%$ & $64.88 \%$ & $76.90 \%$ \\
\hline
\end{tabular}

\section{Tax Saving}

TABLE IX. TAX-SAVING ABILITY

\begin{tabular}{|l|c|c|c|c|c|}
\hline \multirow{2}{*}{ Index (\%) } & \multicolumn{5}{|c|}{ Year } \\
\cline { 2 - 6 } & $\mathbf{2 0 1 3}$ & $\mathbf{2 0 1 4} *$ & $\mathbf{2 0 1 5}$ & $\mathbf{2 0 1 6}^{*}$ & $\mathbf{2 0 1 7}$ \\
\hline IT $^{4}$ & 1019.70 & 1150.60 & 2016.30 & 4067.86 & 4817.00 \\
\hline IT/AA $^{5}$ & $1.18 \%$ & $1.00 \%$ & $1.05 \%$ & $0.93 \%$ & $0.74 \%$ \\
\hline
\end{tabular}

It can be seen from Table 9 that the total Income Tax of the company increased after the merger, which is due to the increase in the number of subsidiaries, total profit increased after M\&A, as result, total Income Tax increase.

Based on the above analysis, the short-term Debt-paying Ability of enterprise has decreased after mergers and acquisitions and long-term Debt-paying Ability has increased. Besides, tax-saving effect has been realized. Thus we can conclude that the financial synergy of mergers and acquisitions can be achieved.

\section{CONCLUSIONS}

After the comparison of a series of financial indicators before and after the merger and acquisition, we find that the growth capability indicators of GEC have been greatly improved. The utilization efficiency of total assets and working capital assets increased slightly, but the operating capacity of the company after mergers and acquisitions did not increase, and the cost control situation remains to be improved. The long-term debt-paying ability of the enterprise has been enhanced and the tax-saving effect has been realized. Therefore, the management synergy effect of M\&A is not obvious, and to some extent, the synergy and financial synergy effects of M\&A are realized.

In this paper, we propose the following suggestions for future mergers and acquisitions based on the financial analysis of case.
On the one hand, choose the companies to merger rationally before action. For example, the merger and merged in this case have mastered the leading technology and intellectual property in this field, which meets the development strategy of GEC to continue to promote technological innovation and service product-upgrade with continuous innovation as the driving force of development. On the other hand, we must pay attention to the post-merger integration stage and prevent integration risks. Only by completing the integration can the synergies be achieved between the parties involved in mergers and acquisitions, and $\mathrm{M} \& \mathrm{~A}$ will be meaningful and successful. Finally, we must pay attention to improving the cost control capabilities of enterprises and try to pay the consideration in the form of non-cash.

\section{REFERENCES}

[1] FLANAGAN D, KR EUZE J, SMITH O M. Merger and acquisition opportunities: Due diligence activities offer internal auditors numerous opportunities to help ensure the success of proposed company integrations [J]. Internal Auditor, 2004, 61 (4): 55- 60.

[2] Cao Cuizhen, Wu Shengwei. Empirical Analysis of Financial Synergies in Enterprise M\&A [J]. Friends of Accounting, 2017(24): 35-39.(In Chinese)

[3] He Luling. Financial Analysis of Synergistic Effect of Enterprise M\&ABased on Case Study of Hanwei Electronics [J]. Finance and Accounting News, 2018(04): 3-8.(In Chinese)

[4] Wang Yisu. Research on the synergy effect of M\&A of listed companies in China's media industry [D]. Henan University, 2017.(In Chinese)

[5] Jiang Nan. Research on the Synergistic Effect of Horizontal Mergers and Acquisitions Based on Financial Perspective-Taking Youku M\&A Potato as an Example [J]. Chinese Certified Public Accountant, 2014(04): 113-118. (In Chinese)

[6] Zou Lu. Analysis of the synergy effect of enterprise mergers and acquisitions from the perspective of finance [J]. Accountant, 2014(12):31-33. (In Chinese)

\footnotetext{
${ }^{2}$ IA: means industry average.

${ }^{3}$ Data from JRJ.COM.

${ }^{4}$ Unit: Ten thousand RMB.

${ }^{5}$ AA: Average Assets.
} 